\title{
Synthesis and Characterization of a Novel Terpolymer Based on L-lactide, D,L-lactide and Trimethylene Carbonate
}

\author{
Adriana Cristina Motta ${ }^{\mathrm{a}, \mathrm{b} *}$, Eliana Aparecida de Rezende Duek ${ }^{\mathrm{a}, \mathrm{b}}$ \\ ${ }^{a}$ Faculdade de Engenharia Mecânica, Universidade Estadual de Campinas - UNICAMP, \\ Cidade Universitária Zeferino Vaz, 1099, CEP 13081-970, Campinas, SP, Brazil \\ ${ }^{\mathrm{b}}$ Laboratório de Biomateriais, CCMB, Pontifícia Universidade Católica de São Paulo-PUC-SP, \\ Praça Dr. José Ermírio de Moraes, 290, CEP 18030-095, Sorocaba, SP, Brazil
}

Received: July 8, 2013; Revised: March 18, 2014

\begin{abstract}
Terpolymers of L-lactide, D,L-lactide and trimethylene carbonate (TMC) were synthesized via the ring-opening polymerization reaction for cyclic monomers using stannous octoate as the initiator at a ratio of $\sim 0.05 \mathrm{~mol} \%$ (monomers/(SnOct) $)_{2}$ ). Synthesis was done at $130{ }^{\circ} \mathrm{C}$ for $48 \mathrm{~h}$. The inclusion of TMC, an aliphatic elastomeric polycarbonate, alongside polymer chain segments containing L-lactide and D,L-lactide, was expected to yield a material with improved properties such as increased elongation; this would overcome the limitation of copolymers consisting entirely of lactide and D,L-lactide. The terpolymer properties were assessed by Nuclear magnetic resonance spectroscopy ${ }^{1} \mathrm{H}$ and ${ }^{13} \mathrm{C}$ NMR, infrared spectroscopy, differential scanning calorimetry and thermogravimetry, with particular attention being given to the effect of TMC on the copolymer of L-lactide-co-D,L-lactide. The mixing of these polymers resulted in material with a high molar mass $\left(10^{5} \mathrm{~g} / \mathrm{mol}\right)$. The mechanical properties of the terpolymer were assessed using pins of this material that were tested by mechanical flexion at three points. When compared with results for the copolymer PLDLA there was a decrease in Young's modulus for the TMC-containing terpolymer.
\end{abstract}

Keywords: bioreabsorbable, properties, synthesis, terpolymer, lactide, D, L lactide, TMC

\section{Introduction}

Aliphatic polyesters are an attractive class of polymers currently used in biomedical and pharmaceutical applications. Prostheses based on bioresorbable polymers have been used for several years ${ }^{1}$ and there is increasing interest in improving the properties of this class of materials as their range of medical applications expands. One reason for the growing interest in these degradable polymers is that their physical and chemical properties can be varied over a wide range by copolymerization and the development of a advanced macromolecular architecture ${ }^{2,3}$.

The ideal biodegradable bone fixation device should have biomechanical properties that provide adequate stability for osteotomy or fracture consolidation. The device should also lose strength over time to ensure that mechanical stress is transferred gradually to the healing bone. The modulus of elasticity of the device should approach the elasticity of bone to prevent stress-protection-induced atrophy that could lead to delayed union or no union ${ }^{4}$.

Bioresorbable elastomeric polymers are widely employed in the medical field, in devices such as implants and porous scaffolds used in tissue engineering ${ }^{5,6}$. Among bioresorbable polymers of interest is the copolymer poly (L,co-D,L-lactic acid; PLDLA) that is widely used in the proportion 70:30 because of its good mechanical properties and excellent biocompatibility. This polymer has been the subject of study of this research group and its synthesis is

*e-mail: motta@fem.unicamp.br; motta.adrianam@gmail.com already consolidated so that the polymer has high molecular weight $^{7-14}$. Though PLA is limited by its inherent brittleness, its properties can be significantly enhanced and broadened by modification via copolymerization, which provides a number of advantages because the architecture and composition of the biomaterials can be tailored to control and composition of the biomaterials can be tailored to control the material properties (by anionic or coordinated polymerization $)^{15}$.

Though, the low elongation values of this copolymer make it susceptible to brittle fracture, which in turn limits its range of applicability. An increase in the elongation value of PLDLA would therefore be useful in expanding the applications of this material.

In the present study, we sought to enhance the elongation value of PLDLA by inserting segments of trimethylene carbonate (TMC), an elastomeric aliphatic polycarbonate, alongside the PLDLA copolymer chain, to enhance the stability of the copolymer. TMC was chosen for the present study because this material has already been used to prepare a variety of biomedical implants ${ }^{16,17}$. An incorporation of aliphatic carbonate units based on TMC into segmented copolymer structure can be a successful method to modify both mechanical properties and rate of biodegradation of aliphatic polyesters. Moreover, polymers based on aliphatic polycarbonate are promising materials with high potential for medical applications due to their biocompatibility, 
low toxicity and susceptibility to biodegradation ${ }^{18}$. Copolymerization of TMC with lactide or glycolide ${ }^{19-22}$, various lactones ${ }^{23,24}$, adipic anhydride ${ }^{25}$, and cyclic imine ${ }^{26}$ have also been reportaded.

The range of applications for terpolymers such as PLDLA-TMC is large and includes fixatives in the form of plates and screws for small fractures, devices for the controlled release of drugs and as porous scaffolds for culturing cells in tissue engineering.

The synthesis of novel polymer structures through ring opening polymerization (ROP) has been studied for several years $^{27-29}$ and is the most popular route for poly( $\alpha$-ester) synthesis. One of the most important factors that influences the properties of aliphatic polyesters is the molecular weight, with high molecular weight materials generally having better mechanical properties. In this work, we sought to optimize the conditions for synthesizing high molar mass PLDLA-TMC ${ }^{30,31}$.

\section{Experimental}

\subsection{Material}

L-lactide and D,L-lactide monomers were obtained from Purac Biochem (The Netherlands) and trimethylene carbonate (1,3 dioxan-2-one) (TMC) was obtained from Boehringer Ingelheim (Germany). The catalyst tin-2-ethyl hexanoate, commonly known as stannous octoate (Sigma), was used as received. TMC was dried under vaccum at room temperature for $12 \mathrm{~h}$ before use. All other chemicals or solvents were reagent grade.

\subsection{Terpolymerization}

Appropriate amounts of L-lactide, D,L-lactide and TMC (L:D,L:TMC $=56: 24: 20$ and 49:21:30, w/w) were mixed and poured into glass ampoules. Stannous octoate was added to a monomer/Sn(Oct) $)_{2}$ molar ratio of $\sim 5000$. The ampoules was sealed under vacuum and then immersed in an oil bath at $130{ }^{\circ} \mathrm{C}$ for $48 \mathrm{~h}$. At the end of the reaction, the ampoules were opened and the contents were dissolved in chloroform and precipitated in methanol. The terpolymer was dried under vacuum for $8 \mathrm{~h}$ at $45^{\circ} \mathrm{C}$ to eliminate residual solvent.

\subsection{Characterization}

The terpolymer composition was determined by ${ }^{1} \mathrm{H}-\mathrm{NMR}$ and ${ }^{13} \mathrm{C}-\mathrm{NMR}$. The spectra were recorded in $\mathrm{CDCL}_{3}$ referenced to tetramethylsilane (TMS) as an internal standard in a Bruker AC-300P spectrometer $(300 \mathrm{MHz}$ and $75 \mathrm{MHz}$, respectively). Five millimeter samples tubes were used. The spectra were obtained at $25^{\circ} \mathrm{C}$. FT-IR spectra were obtained with a Bomen spectrometer at $4000-650 \mathrm{~cm}^{-1}$ after casting the films from methylene chloride solutions onto $\mathrm{NaCl}$ pellets.

The molecular weight was estimated by size exclusion chromatography (CLWA-1) with Tetrahydrofuran (THF) as the mobile phase and polysterene $\left(10^{2}, 10^{4}\right.$ and $\left.10^{5} \mathrm{~nm}\right)$ as standards. All determinations were done at $25^{\circ} \mathrm{C}$.

Differential scanning calorimetry (DSC) was done using a Perker-Elmer equipped with a low-temperature accessory. The DSC measurements were done at a heating rate of $10^{\circ} \mathrm{C} /$ $\mathrm{min}$ in a nitrogen atmosphere and in the temperature range of $-50{ }^{\circ} \mathrm{C}$ to $200{ }^{\circ} \mathrm{C}$. The glass transition temperature $(\mathrm{Tg})$ was taken at the midpoint of the stepwise specific heat increment.

Thermogravimetric analysis (TGA) was done using a Netzsch STA499C thermal analyzer. The samples were heated from room temperature to $500{ }^{\circ} \mathrm{C}$ at a heating rate of $10{ }^{\circ} \mathrm{C} \mathrm{min}-1$ in an argon atmosphere.

\subsection{Preparation of pins for evaluation of mechanical properties and morphology}

Dense pins of PLDLA and PLDLA-TMC were prepared to compare them by fusion in a mold ( $2.5 \mathrm{~mm}$ diameter) using a Mini Max Molder (LMM-2017, Austin, TX, USA) at $220{ }^{\circ} \mathrm{C}$. The mold was cooled at room temperature. The mechanical properties of the PLDLA and PLDLA-TMC pins were tested by the three-point bending method, according to ASTM D 790-95A in an MTS TestStar II using a cell load of $100 \mathrm{kgf}$ (bottom scale: $20 \mathrm{kgf}$ ), at a speed of $5 \mathrm{~mm} / \mathrm{min}$. The distance between the two ends was $2 \mathrm{~cm}$.

Pin morphology was studied with a scanning electron microscope (SEM). Sample were coated with gold using a sputter-coater (BAL-TEC SCD 050), and the microscope was operated at $10 \mathrm{kV}$.

\section{Results and Discussion}

\subsection{Synthesis of PLDLA-TMC terpolymers}

Polymerization was done by the ring-opening bulk procedure as shown in Scheme 1. Stannous octoate was selected as it is highly efficient and commonly used in the preparation of polymers for biomedical applications $\mathrm{s}^{32}$. A series of segments containing lactide, D, L lactide and TMC have been synthesized - Table 1 . The molar fraction of L- and D,L-lactide was fixed ( $70 \% \mathrm{~L} ; 30 \% \mathrm{D}, \mathrm{L}$ ) while that of TMC was varied ( $20 \%$ or $30 \%$ of TMC by weight) (Table 1) Terpolymerization was done at $130{ }^{\circ} \mathrm{C}$ for $48 \mathrm{~h}$. Variation in the amount of TMC along the polymer chain was seen as fluctuations in the intensity of the NMR peaks, as noted below.

Table 1. Data on terpolymer l-lactide, D,L lactide and TMC synthesized by polymerization in bulk $130{ }^{\circ} \mathrm{C}, 48$ hours.

\begin{tabular}{lccc}
\hline \multicolumn{1}{c}{ Synthesis } & \% mol L-lactide & \% mol D,L lactide & \% mol TMC \\
\hline PLDLA-TMC (20\% TMC) & 55.3 & 18.4 & 26.3 \\
PLDLA-TMC (30\% TMC & & & 37.4 \\
First synthesis & 44.0 & 18.6 & 38.2 \\
Second synthesis & 43.3 & 18.6 & 37.4 \\
Third synthesis & 44.0 & 18.6 & 37.4 \\
Fourth synthesis & 44.0 & 18.6 & 37.3 \\
Fifth synthesis & 43.8 & 18.8 & \\
\hline
\end{tabular}


<smiles>O=C1OCCC[O+]1</smiles>

TMC<smiles>CC1OC(=O)C(C)OC1=O</smiles>

LLA<smiles>CCO[AsH2]</smiles>

DLLA<smiles>CC(OC(=O)C(C)(C)C(=O)OCCCOC(C)(C)C(C)(C)C)C(=O)OC(C)C(=O)C(C)(C)C</smiles>

LDLA - TMC

Scheme 1. Polymerization procedure for the synthesis of terpolymer derived from TMC, LLA and DLLA.

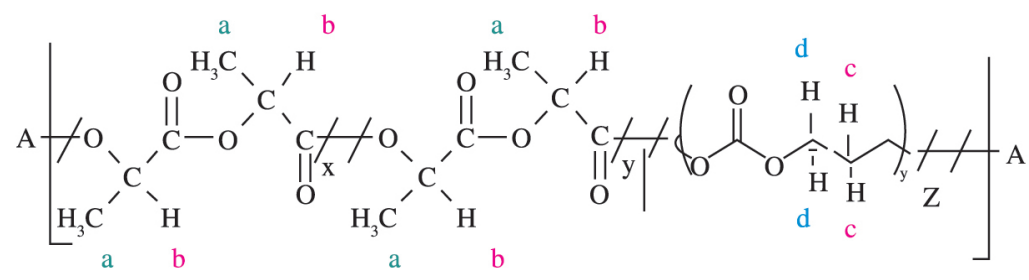

Figure 1. Hydrogen residues corresponding to L-lactide, D,L-lactide and TMC.

\subsection{Molecular structure of the terpolymer}

The hydrogen residues corresponding to L-lactide, D,Llactide and TMC were assigned based on the terpolymer structure (Figure 1).

\subsection{Proton nuclear magnetic resonance $\left({ }^{1} H-N M R\right)$}

The terpolymer composition was determined by ${ }^{1} \mathrm{H}-\mathrm{NMR}$. The signals detected in the ${ }^{1} \mathrm{H}-\mathrm{NRM}$ terpolymer were practically the same as those for the poly(L-lactic-coD,L-lactic acid) copolymer, differing only in two offsets that were characteristic of the presence of TMC and could be checked at $\delta 2.05 \mathrm{ppm}\left(\mathrm{CH}_{2}-\mathrm{TMC}\right)$ and $\delta 4.24 \mathrm{ppm}$ $\left(\mathrm{OCH}_{2}-\mathrm{TMC}\right)^{[33]}$. Figure 2 compares the ${ }^{1} \mathrm{H}-\mathrm{NMR}$ spectra of the copolymer PLDLA and the terpolymer PLDLA-TMC. In the copolymer spectrum, a multiplet at 5.12-5.24 ppm was assigned to the $\mathrm{CH}$ proton (b), while the quartet at 1.55-1.59 ppm was assigned to the $\mathrm{CH}_{3}$ protons $(\mathrm{a})^{[34]}$. In the case of PLDLA-TMC, the triplet at $2.05 \mathrm{ppm}$ was assigned to the $\mathrm{CH}_{2}$ protons (c), while the triplet at 4.24 ppm was assigned to $\mathrm{OCH}_{2}$ (d).

The only difference between the spectra for PLDLA (spectrum $h$ ) and PLDLA-TMC (spectrum $i$ ) was the presence of peaks corresponding to the protons of TMC. This finding indicated that the appropriate conditions had been used to synthesize the terpolymer. Figure 3 shows the ${ }^{1} \mathrm{H}-\mathrm{NMR}$ spectra for PLDLA-TMC obtained using $20 \%$ (spectrum $j$ ) and $30 \%$ (spectrum $k$ ) TMC. These two concentrations were used to facilitate identification of the peaks corresponding to protons of TMC (slightly greater with the higher concentration). Figure 4 shows the proton peaks obtained with $30 \%$ TMC in greater detail.

Okada $^{35}$ suggested that the small peaks in the region of $4.48 \mathrm{ppm}$ corresponded to traces of residual monomer. The ${ }^{1} \mathrm{H}-\mathrm{NMR}$ spectra obtained here clearly indicated the presence of protons contributed by TMC and PLDLA.

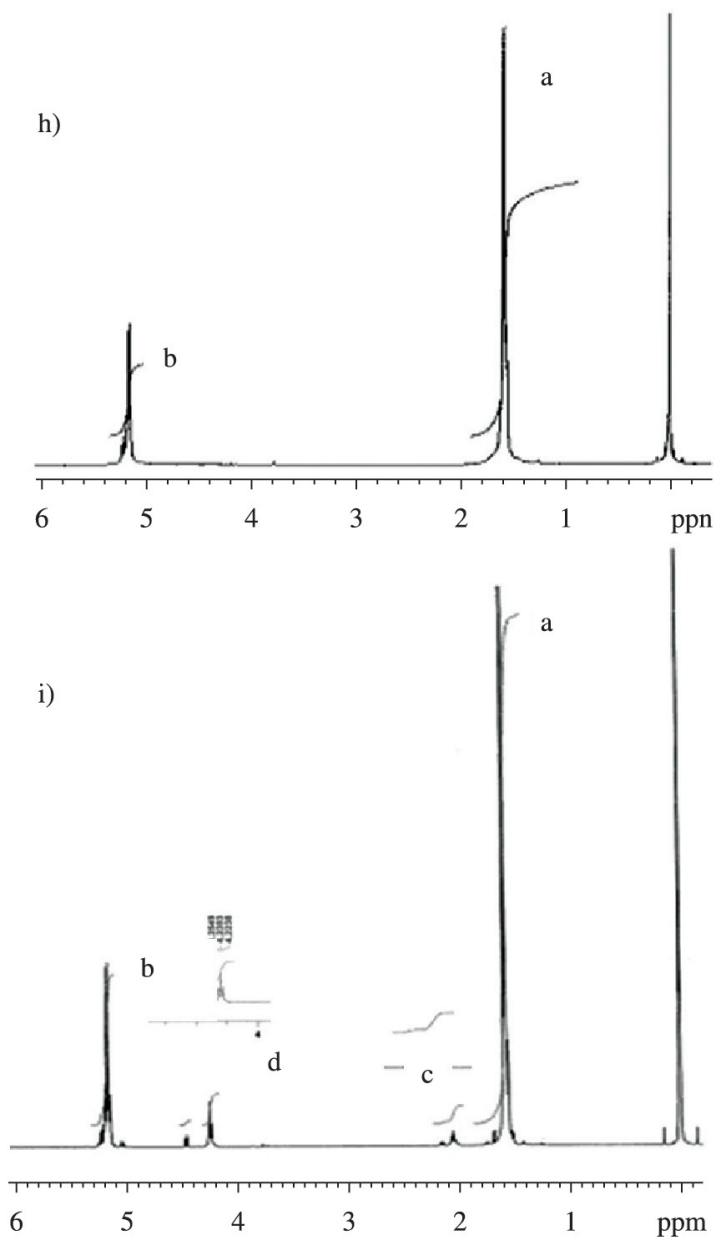

Figure 2. Comparison of the $h$ spectrum for PLDLA and the $i$ spectrum for PLDLA-TMC. Note the protons characteristic of TMC in the latter spectrum. 


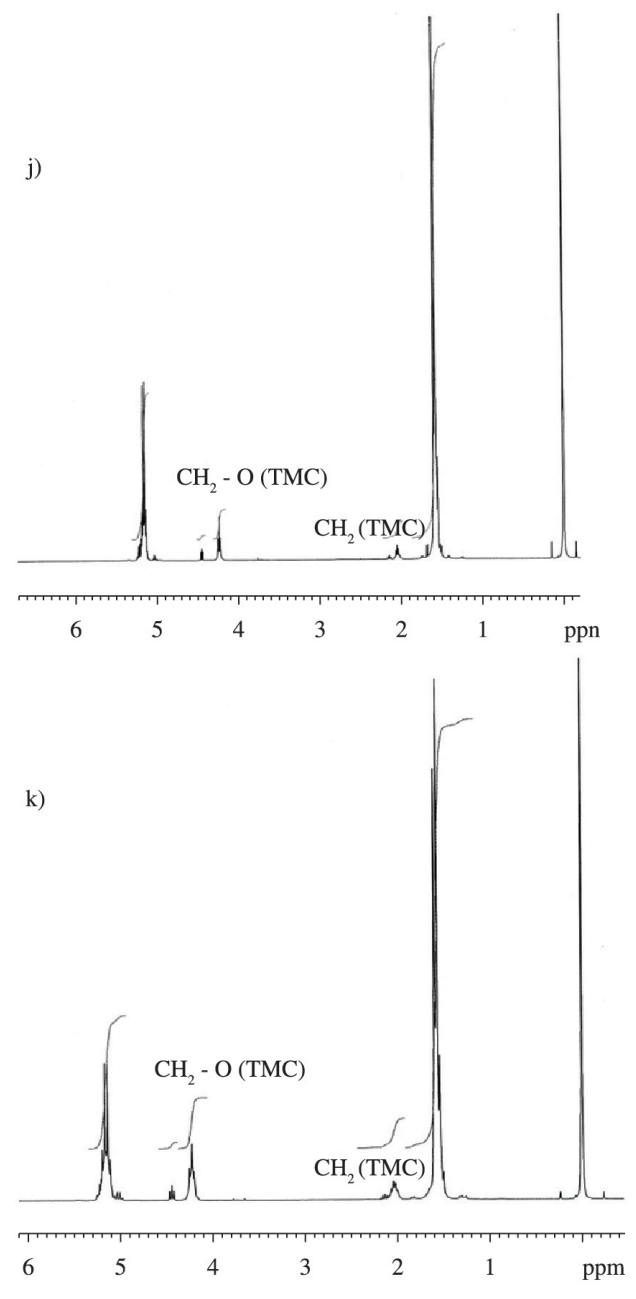

Figure 3. Comparison of the spectra for PLDLA-TMC obtained using 20\% (spectrum $j$ ) and 30\% (spectrum $k$ ) TMC. Note the enhanced proton peaks obtained with the higher concentration of TMC.
${ }^{1} \mathrm{H}-\mathrm{NMR}$ was also used to calculate the amount of unconverted monomer during polymerization. This was done by integrating the peaks corresponding to the protons of the methyl groups in PLDLA and the $\mathrm{CH}_{2}$ protons belonging to TMC, as described by Buchholz ${ }^{19}$. Table 2 shows the starting concentrations of TMC and the composition detected by ${ }^{1} \mathrm{H}-\mathrm{NMR}$.

According to Ruckenstein et al. ${ }^{36}$ the rate of conversion of the LLA monomer is greater than the rate of reaction of the TMC cyclic monomer, which explains the presence of fewer units of these molecules linked to TMC in the polymer chain.

\subsection{Carbon-13 nuclear magnetic resonance $\left({ }^{13} \mathrm{C}-\mathrm{NMR}\right)$}

The ${ }^{13} \mathrm{C}$-NMR signals obtained for PLDLA-TMC agreed completely with those obtained for the individual units that constitute the terpolymer. Table 3 shows the ${ }^{13} \mathrm{C}$-NMR signals for the individual constituents of the terpolymer compared to the corresponding values reported in the literature. The presence of signals characteristic of PLDLA and TMC indicated that the synthesis of PLDLA-TMC was successful. Figure 5 shows the ${ }^{13} \mathrm{C}$-NMR spectrum of the terpolymer.

\subsection{Infrared (IR) absorption spectra}

IR absoprtion spectra are very useful for analyzing TMC and lactide copolymers. Specifically, the bands attributed to the presence of TMC occur at $1745 \mathrm{~cm}^{-1}(\mathrm{C}=\mathrm{O})$ and $1247 \mathrm{~cm}^{-1}$ (OCO), the latter involving asymmetrical stretching, while the bands corresponding to PLDLA occur at $1757 \mathrm{~cm}^{-1}$ and $1185 \mathrm{~cm}^{-1}$ (C=O and COC, respectively $)^{[36]}$. Figure 6 shows the Fourier-transform IR (FTIR) spectrum of PLDLA and PLDLA-TMC,

\subsection{Gel permeation chromatography}

The molar mass is an important parameter in classifying polymers and their mechanical properties.

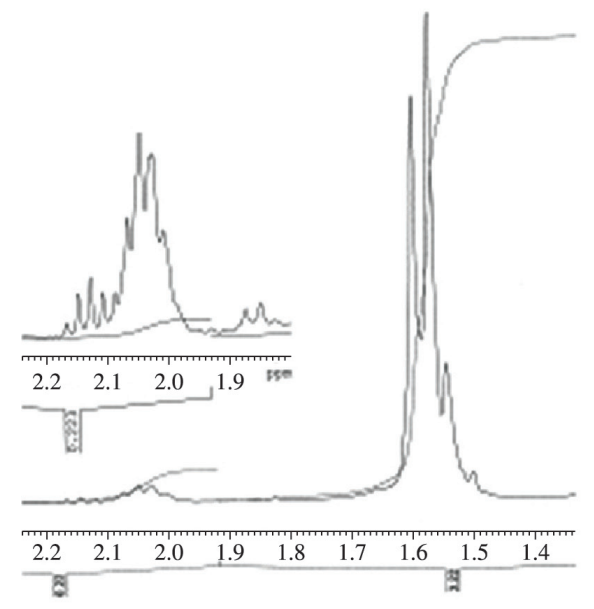

(b)

Figure 4. Amplification of the regions corresponding to the protons peaks of TMC in the $\mathrm{H}^{1}$-NMR spectra of PLDLA-TMC synthesized with $30 \%$ TMC. (a) and (b) - Proton peaks corresponding to $\mathrm{OCH}_{2}-\mathrm{TMC}$ and $\mathrm{CH}_{2}-\mathrm{TMC}$, respectively. 
Table 2. TMC concentrations and terpolymer compositions calculated from ${ }^{1} \mathrm{H}-\mathrm{NMR}$ spectra.

\begin{tabular}{ccccc}
\hline Synthesis & $\begin{array}{c}\text { Initial TMC } \\
\text { concentration (\%) }\end{array}$ & $\begin{array}{c}\text { Final TMC } \\
\text { concentration (\%) }\end{array}$ & $\begin{array}{c}\text { Conversion (\%) } \\
\text { Folymer composition } \\
\text { (DLLA/TMC) (\%) }\end{array}$ \\
\hline First & 20 & 16 & 80 & $84 / 16$ \\
Second & 30 & 28 & 93 & $72 / 28$ \\
\hline
\end{tabular}

Table 3. ${ }^{13} \mathrm{C}-\mathrm{NMR}$ signals for PLDLA and TMC.

\begin{tabular}{lcccccc}
\hline & \multicolumn{3}{c}{ PLDLA } & \multicolumn{3}{c}{ TMC } \\
\hline & $\mathbf{C H}_{3}$ & $\mathbf{C H}$ & $\mathbf{C}=\mathbf{O}$ & $\mathbf{C H}_{2} \mathbf{C H}_{2} \mathbf{C H}_{2}$ & $\mathbf{C H}_{2} \mathbf{O}$ & $\mathbf{C}=\mathbf{O}$ \\
\hline Signal detected & 16.6 & 69 & 169.6 & 27.8 & 61.864 .7 & 154.8 \\
Signal reported by Matsumura, $19999^{[20]}$ & 16.7 & 69 & 169.6 & 27.9 & 61.864 .0 & 154.4 \\
\hline
\end{tabular}

Table 4. Gel permeation chromatography analysis of PLDLA-TMC synthesized by ring-opening polymerization catalyzed with $\operatorname{Sn}(\mathrm{Oct}){ }_{2}$.

\begin{tabular}{lccc}
\hline \multicolumn{1}{c}{ Synthesis } & $\mathbf{M}_{\mathrm{w}}(\mathbf{g} / \mathbf{m o l})$ & $\mathbf{M}_{\mathbf{n}}(\mathbf{g} / \mathbf{m o l})$ & $\mathbf{I p}_{\mathbf{w}}\left(\mathbf{M}_{\mathbf{w}} / \mathbf{M}_{\mathbf{n}}\right)$ \\
\hline PLDLA-TMC (20\% TMC) & 127630 & 69694 & 1.7 \\
PLDLA-TMC (30\% TMC) & & & 2.0 \\
First synthesis & 126577 & 60451 & 1.2 \\
Second synthesis & 105289 & 84863 & 1.3 \\
Third synthesis & 141085 & 110059 & 1.0 \\
Fourth synthesis & 200646 & 198076 & 1.3 \\
Fifth synthesis & 200198 & 152594 & \\
\hline
\end{tabular}

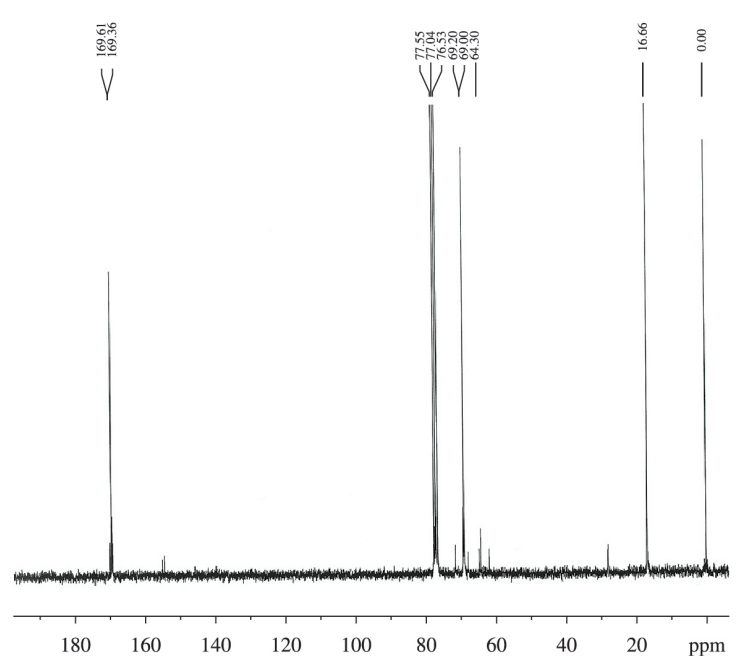

Figure 5. ${ }^{13} \mathrm{C}-\mathrm{NMR}$ spectrum of PLDLA-TMC.

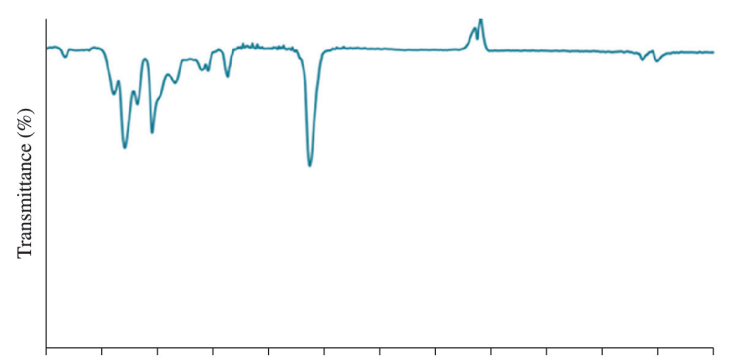

$\begin{array}{lllllllllllll}800 & 1000 & 1200 & 1400 & 1600 & 1800 & 2000 & 2200 & 2400 & 2600 & 2800 & 3000 & 3200\end{array}$ Wavenumbers $\left(\mathrm{cm}^{-2}\right)$ - PLDLA-TMC

Figure 6. FTIR spectra of PLDLA-TMC.
Table 4 shows that the molar mass of PLDLA-TMC was in the order of $10^{5} \mathrm{~g} / \mathrm{mol}$, which is characteristic of high molecular weight polymers. This is an important feature in order to obtain materials that present good mechanical performance during a period of implantation, what is required for a large number of applications ranging from fracture fixation to polymeric scaffolds. The starting molecular weight influences the total time of degradation of a device ${ }^{37}$. The physical properties of a polymer are directly dependent on its molecular weight.By preparing high molecular weight polymers one can obtain materials with good mechanical performance, even after processing methods that can induce chain scission like melt processing or sterilization by gamma irradiation ${ }^{30}$. Independently of the degradation mechanism of the polymer, the onset of loss of mechanical properties and mass is delayed with increasing initial molecular weight of the material.

The polydispersity values of all terpolymers are between 1-2.These values This has been reported before for lactone ring-opening polymerizations ${ }^{38}$.

The conditions used to obtain the terpolymer, viz., a monomer/catalyst ratio of $\sim 5000$, a temperature of $130{ }^{\circ} \mathrm{C}$ and a synthesis time of $48 \mathrm{~h}$, allowed polymerization of the high molecular weight material, the properties of which could be checked by GPC analysis.

\subsection{Differential scanning calorimetry (DSC)}

All of the terpolymers prepared in this study were amorphous, with no melting point. Figure 7 shows a typical thermogram for the second heating curve; the first heating scan showed a unique glass transition $(\mathrm{Tg})$ around $50{ }^{\circ} \mathrm{C}$. Table 5 shows typical phase transition values for these amorphous terpolymers as measured by DSC. 
The amorphous nature of the copolymer, together with its lower degradation and greater flexibility, provide important advantages compared to the homopolymer PLLA, which is highly crystalline. This is particularly the case when the time required for application is short. Comparison of this PLDLA-TMC terpolymer with the PLDLA copolymer studied by Motta ${ }^{14}$ shows that there was a slight decrease in the $\mathrm{Tg}$ from $58{ }^{\circ} \mathrm{C}$ (PLDLA) to $47^{\circ} \mathrm{C}$ (PLDLA-TMC); this decrease reflected the flexibility of TMC inherent in the terpolymer chain.

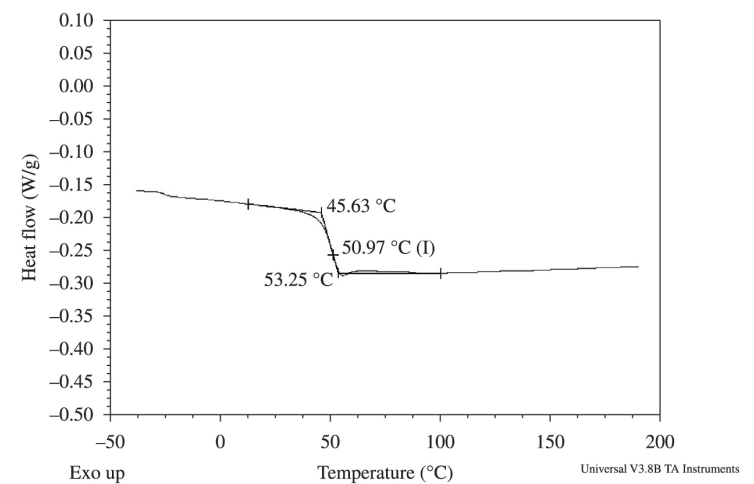

Figure 7. DSC thermogram for the second heating of PLDLA-TMC.

Table 5. Glass transition temperatures $(\mathrm{Tg})$ for the second heating of PLDLA and PLDLA-TMC as determined by DSC.

\begin{tabular}{lc}
\hline \multicolumn{1}{c}{ Synthesis } & $\mathbf{T}_{\mathbf{g}}\left({ }^{\circ} \mathbf{C}\right)$ \\
\hline PLDLA & 57 \\
PLDLA-TMC (30\% TMC) & \\
First synthesis & 48 \\
Second synthesis & 51 \\
Third synthesis & 50 \\
Fourth synthesis & 51 \\
Fifth synthesis & 49 \\
\hline
\end{tabular}

Table 6. Thermal properties of PLDLA-TMC obtained using 20\% and $30 \%$ TMC and PLDLA.

\begin{tabular}{lcc}
\hline \multicolumn{1}{c}{ PLDLA-TMC } & T onset $\left({ }^{\circ} \mathbf{C}\right)$ & T peak $\left({ }^{\circ} \mathbf{C}\right)$ \\
\hline $20 \%$ TMC & 321 & 342 \\
$30 \%$ TMC & 323 & 346 \\
PLDLA & 330 & 355 \\
\hline
\end{tabular}

Table 7. Mechanical properties of PLDLA and PLDLA-TMC $30 \%$.

\begin{tabular}{lcc}
\hline \multicolumn{1}{c}{ Polymer } & $\begin{array}{c}\text { Young's modulus } \\
(\mathbf{E})(\mathbf{M P a})\end{array}$ & $\begin{array}{c}\text { Tension max } \\
(\mathbf{M P a})\end{array}$ \\
\hline PLDLA & $3133 \pm 200$ & $49.9 \pm 2.6$ \\
PLDLA-TMC & $970 \pm 220$ & $26.7 \pm 0,9$ \\
\hline
\end{tabular}

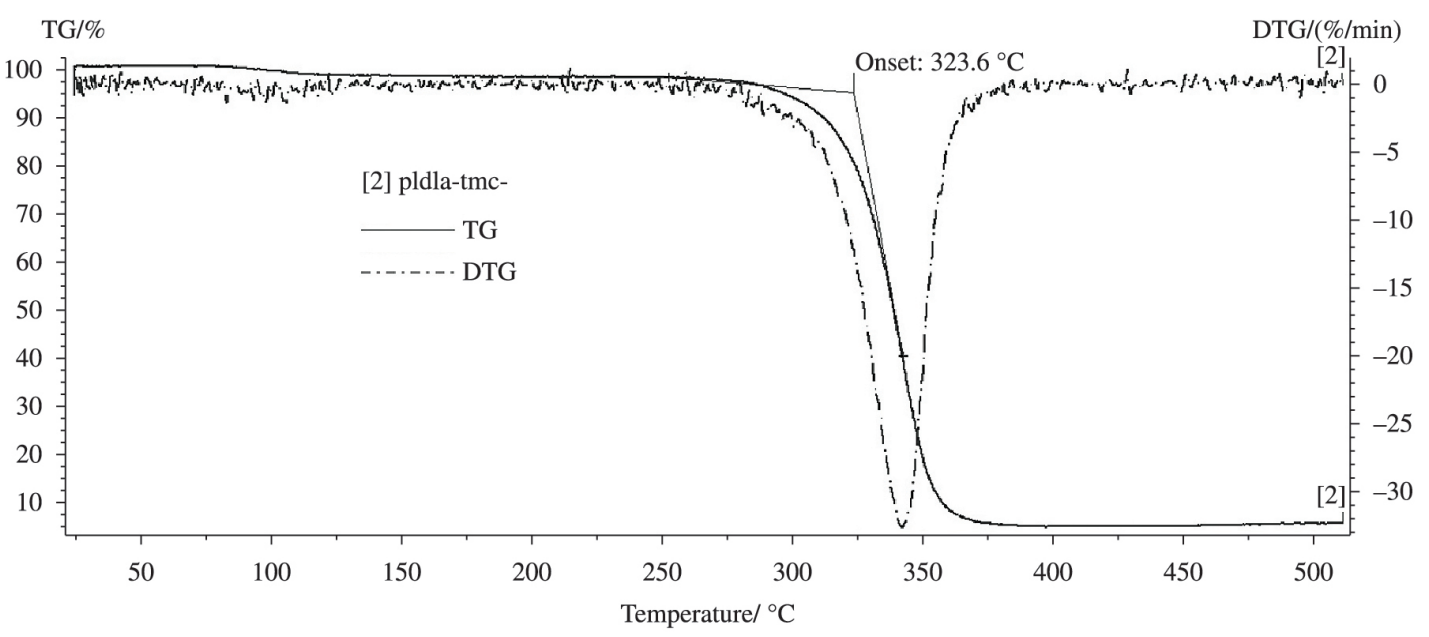

Figure 8. TGA of PLDLA-TMC.

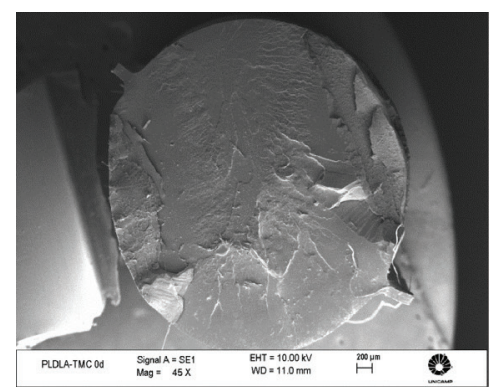

(a)

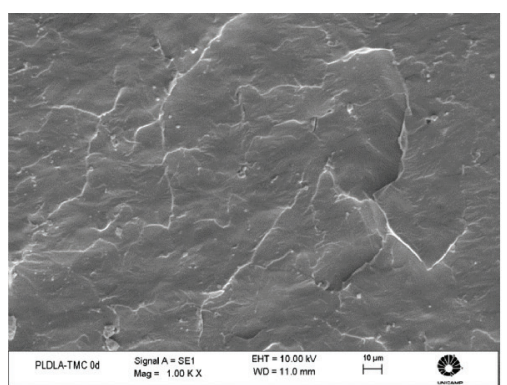

(b)

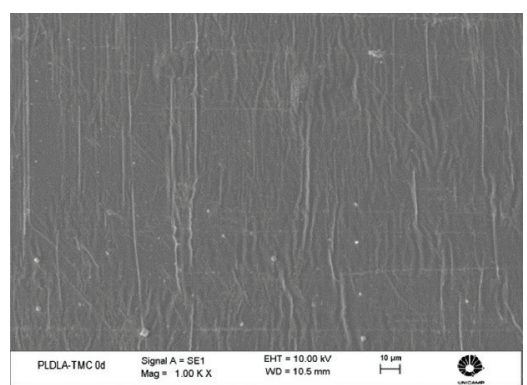

(c)

Figure 9. SEM micrographs of PLDLA-TMC pin. a) fracture surfaces b) surface. Magnifications bars $200 \mathrm{~nm}$ for (a), $10 \mathrm{~nm}$ for (b) and $10 \mathrm{~nm}$ for (c). 


\subsection{Thermal gravimetric analysis (TGA)}

The thermal stability of the terpolymer was analyzed by by TGA. Figure 8 shows the thermogravimetric curve for the synthesis of PLDLA-TMC. Table 6 shows the temperature of onset of loss of mass and the temperature at which the loss of mass was maximum for each terpolymer synthesized. The concentration of TMC $(20 \%$ or $30 \%)$ did not affect the temperature of the onset of degradation.

\subsection{Mechanical properties of PLDLA-TMC and morfology}

Table 7 summarizes the mechanical properties of PLDLA-TMC. The high modulus and strength of PLDLA reflected the stiffness of this copolymer. In contrast, PLDLA-TMC showed a decreased in modulus because of the presence of TMC. This feature suggests that PLDLATMC may useful for implants in soft tissue engineering.

It is noted that both the surface and the fracture surface of the pins have a completely dense morphology characteristic of devices obtained by the melting process, and also suitable for applications aimed fracture fixation (Figure 9).

\section{References}

1. Davachi SM, Kaffashi B, Roushandeh JM and Torabinejad B. Investigating thermal degradation, crystallization and surface behavior of L-lactide, glycolide and trimethylene carbonate terpolymers used for medical applications. Materials Science and Engineering C. 2012; 32:98-104. http://dx.doi. org/10.1016/j.msec.2011.10.001

2. Zurita A, Puiggali J, Franco L and Rodriguez-Galan A. Copolymerization of glycolide and trimethylene carbonate. Journal of Polymer Science Part A: Polymer Chemistry. 2006; 44(2):993-1013. http://dx.doi.org/10.1002/ pola.21199

3. Pêgo AP, Siebum B and Grijpma D. Preparation of Degradable Porous Structures Based on 1,3-Trimethylene Carbonate and D,L-Lactide (Co)polymers for Heart Tissue Engineering. Tissue Engineering. 2003; 9:981-993. PMid:14633382. http://dx.doi. org/10.1089/107632703322495628

4. Celorio ED, Franco L, Gala AR and Puiggali J. Preparation of Degradable Porous Structures Based on 1,3-Trimethylene Carbonate and D,L-Lactide (Co)polymers for Heart Tissue Engineering. European Polymer Journal. 2012; 48:60-73. http://dx.doi.org/10.1016/j.eurpolymj.2011.10.014

5. Stock UA and Vacanti JP. Tissue engineering: Current state and prospects. Annual Review of Medicine. 2001; 52:443. PMid: 11160788 . http://dx.doi.org/10.1146/annurev. med.52.1.443

6. Wang Y, Bella E, Lee CS, Migliaresi C, Pelcastre L, Schwartz $\mathrm{Z}$ et al. The synergistic effects of $3-\mathrm{D}$ porous silk fibroin matrix scaffold properties and hydrodynamic environment in cartilage tissue regeneration. Biomaterials. 2010; 31(17):46724681. PMid:20303584. http://dx.doi.org/10.1016/j. biomaterials.2010.02.006

7. Ciambelli GS, Perez MO, Siqueira GV, Candella MA, Motta AC, Duarte MA et al. Characterization of poly (L-co-D,L Lactic Acid) and a study of polymer-tissue interaction in subcutaneous

\section{Conclusion}

Terpolymers of L-lactide, D,L-lactide and TMC were synthesized by the ring-opening bulk copolymer method, using stannous octoate as the catalyst. The conditions used (reaction done at $130{ }^{\circ} \mathrm{C}$ for $48 \mathrm{~h}$ ) generated high molecular weight material $\left(10^{5} \mathrm{~g} / \mathrm{mol}\right)$, as interest increases in biodegradable polyesters for use in biomedical applications, since it physical properties of a polymer are directly dependent on its molecular weight. The molecular structures, thermal properties, as well as the mechanical properties of material were determined using ${ }^{1} \mathrm{H}-\mathrm{NMR}$, ${ }^{13} \mathrm{C}-\mathrm{NMR}$ and IR. Thermal analysis by DSC showed that the terpolymer was amorphous ( $\mathrm{Tg}$ of $\sim 48^{\circ} \mathrm{C}$ ). The thermal stability measured by TGA showed that the temperature for the onset of degradation was $\sim 290{ }^{\circ} \mathrm{C}$ and there was a decrease in the modulus as a function of the presence of TMC. The degradability of these tercopolymers in vitro and in vivo will be investigated in future studies.

\section{Acknowledgments}

A.C. Motta acknowledges the MS/SUS program for her research.

implants in wistar rats. Materials Research. 2013; 16:28-37. http://dx.doi.org/10.1590/S1516-14392012005000146

8. Messias AD, Lucchesi C, Coraça-Huber DC, Pavani Filho A and Duek EAR. Lithograph-moulded poly-L-co-D,L lactide porous membranes for osteoblastic culture. Materials Research. 2014; 17(1):7-15. http://dx.doi.org/10.1590/S151614392013005000156

9. Stares SL, Boehs L, Fredel MC, Aragonês A and Duek EAR. Self-reinforced bioresorbable polymer P (L/DL) LA 70:30 for the manufacture of craniofacial implant. Polímeros. 2012; 22:378-383. http://dx.doi.org/10.1590/S010414282012005000056

10. Baraúna G, Coraça-Huber DC and Duek EAR. In vitro degradation of Poly-L-co-D, L-lactic acid membranes. Materials Research. 2012; 16:221-226. http://dx.doi. org/10.1590/S1516-14392012005000154

11. Motta AC and Duek EAR. Síntese, Caracterização e degradação in vitro do poli(lácido lático-co-D,L ácido glicólico). Matéria. 2006; 11(3):340-350. http://dx.doi.org/10.1590/ S1517-70762006000300024

12. Baraúna GS, Pierucci A, Oliveira A, Duarte MAT and Duek EAR. Estudo da degradação "in vivo" de poli(L-coD,L-ácido láctico) aplicado como prótese para regeneração nervosa periférica. Matéria. 2007; 12:298-306. http://dx.doi. org/10.1590/S1517-70762007000200008

13. MottaAC and Duek EAR. Síntese e caracterização do copolímero poli (L-co-D,L Ácido Láctico). Polímeros. 2007; 17:123-29. http://dx.doi.org/10.1590/S0104-14282007000200011

14. Motta AC. Síntese, caracterização de dispositivos de poli( L-coD, Lácido lático). Estudo da degradação "in vitro" e "in vivo". [Tese]. Campinas: Universidade Estadual de Campinas; 2007.

15. Kim JK and Lee JH. Preparation and chain-extension of P(LLAb-TMC-b-LLA) triblock copolymers and their elastomeric properties. Macromolecular Research. 2002; 10(2):54-59. http://dx.doi.org/10.1007/BF03218290 
16. Engelberg I and Kohn J. Physico-mechanical properties of degradable polymers used in medical applications: A comparative study. Biomaterials. 1991; 12(3):292-304. http:// dx.doi.org/10.1016/0142-9612(91)90037-B

17. Middeleton JC and Tipton AJ. Physico-mechanical properties of degradable polymers used in medical applications: A comparative study. Biomaterials. 2000; 21:2335-2346. http:// dx.doi.org/10.1016/S0142-9612(00)00101-0

18. Krasowska K, Heimowska A and Rutkowska M. Enzymatic and hydrolytic degradation of poly (-caprolactone) in natural environment. Polimery. 2006; 51:21-26.

19. Buchholz B. Analysis and characterization of resorbable DL-lactide-trimethylene carbonate copolyesters. Journal of Materials Science: Materials in Medicine. 1993; 4:381-388. http://dx.doi.org/10.1007/BF00122196

20. Matsumura S, Tsukada K and Toshima K. Novel lipasecatalyzed ring-opening copolymerization of lactide and trimethylene carbonate forming poly(ester carbonate) s. International Journal of Biological Macromolecules. 1999; 25(1-3):161-167. http://dx.doi.org/10.1016/S01418130(99)00030-6

21. Grijpma DW and Pennings AJ. (Co)polymers of L-lactide, 1. Synthesis, thermal properties and hydrolytic degradation. Macromolecular Chemistry and Physics. 1994; 195:1633. http://dx.doi.org/10.1002/macp.1994.021950515

22. Storey RF and Hickey TP. Methacrylate-endcapped poly(d,l-lactide-co-trimethylene carbonate) oligomers. Network formation by thermal free-radical curing. Polymer. 1997; 38:6295-6301. http://dx.doi.org/10.1016/ S0032-3861(97)00208-5

23. Paturej M., Fray M. E. Syntheses of new poly(ester-carbonateurethane)s based on trimethylene carbonate (TMC) and polyester polyol derived from dimerized fatty acid. Polimery. 2009, 54: 610-617

24. Shen Y, Shen Z, Zhang Y and Yao K. Novel Rare Earth Catalysts for the Living Polymerization and Block Copolymerization of ع-Caprolactone. Macromolecules. 1996;29:8289-8295. http:// dx.doi.org/10.1021/ma9518060

25. Albertsson AC and Liu Y. Comparison Between Physical Blending and Copolymerization of Poly(Trimethylene Carbonate) and Poly(Adipic Anhydride) with Special Regard to Compatibility, Morphology, and Degradation. Journal of Macromolecular Science: Pure and Applied Chemistry. 1997; A34(8):1457-1482. http://dx.doi. org/10.1080/10601329708011056

26. Nomura R, Kori M and Matsuda H. Copolymerization of cyclic imines and cyclic carbonates in the presence of triethylamine, -phosphine or -stibine. Macromolecular Chemistry and Physics. 1988; 9:739-742.

27. Jerome $\mathrm{C}$ and Lecomte P. Recent advances in the synthesis of aliphatic polyesters by ring-opening polymerization. Advanced
Drug Delivery Reviews. 2008; 60:1056-1076. PMid:18403043. http://dx.doi.org/10.1016/j.addr.2008.02.008

28. Albertsson AC and Varma IK. Recent Developments in Ring Opening Polymerization of Lactones for Biomedical Applications. Biomacromolecules. 2003; 4:1466-1486. PMid:14606869. http://dx.doi.org/10.1021/bm034247a

29. Fernandez J, Etxeberria A and Sarasua JR. Synthesis, structure and properties of poly(L-lactide-co- $\varepsilon$-caprolactone) statistical copolymers. Journal of the Mechanical Behavior of biomedical Materials. 2012; 9:100-112. PMid:22498288. http://dx.doi. org/10.1016/j.jmbbm.2012.01.003

30. Oepen V and Michaeli W. Injection moulding of biodegradable implants. Clinical Materials. 1992; 10:21-28. http://dx.doi. org/10.1016/0267-6605(92)90080-D

31. Gogolewski S and Jovanoviv M. The effect of melt-processing on the degradation of selected polyhydroxyacids: polylactides, polyhydroxybutyrate, and polyhydroxybutyrate-co-valerates. Polymer Degradation and Stability. 1993; 40:313-322. http:// dx.doi.org/10.1016/0141-3910(93)90137-8

32. Raul Z, Jordi P and Alfonso RG. Triclosan Release from Coated Polyglycolide Threads. Macromolecular Bioscience. 2006; 6:58-69. PMid:16374771. http://dx.doi. org/10.1002/mabi.200500147

33. Pospiech D, Komber H and Jehnichen D. Multiblock Copolymers of 1-Lactide and Trimethylene Carbonate. Biomacromolecules. 2005; 6:439-446. PMid:15638550. http:// dx.doi.org/10.1021/bm049393a

34. Thakur K, Kean R, Hall E, Kolstad J, Lindgren T, Doscotch $\mathrm{M}$ et al. High-Resolution ${ }^{13} \mathrm{C}$ and ${ }^{1} \mathrm{H}$ Solution NMR Study of Poly(lactide). Macromolecules. 1997; 30:2422. http://dx.doi. org/10.1021/ma9615967

35. Okada T, Imamura Y and Matsuda T. Polymerization of trimethylene carbonate in aqueous solutions: Reaction mechanism and characterization. Polymer Chemistry. 2010; 1485-1492.

36. Ruckenstein E and Yuan Y. Molten ring-open copolymerization of L-lactide and cyclic trimethylene carbonate. Journal of Applied Sciene. 1998; 69:1429-1434. http://dx.doi. org/10.1002/(SICI)1097-4628(19980815)69:7<1429::AIDAPP18>3.0.CO;2-O

37. Pêgo AP. Biodegradable polymers based on Trimethylene carbonate For tissue engineering applications. [Dissertation]. Enschede: University of Twente; 2002.

38. Albertsson AC and Eklund M. Synthesis of copolymers of 1,3-dioxan-2-one and oxepan-2-one using coordination catalysts. Journal of Polymer Science Part A: Polymer Chemistry. 1994; 32:265-279. http://dx.doi.org/10.1002/ pola.1994.080320207 